Original Research

\title{
The Effectiveness of Chewing Gum versus Cryotherapy on Salivary Volume among Patient with Head and Neck Cancer Undergoing Radiotherapy
}

\section{Dwi Uswatun Sholikhah, I Ketut Sudiana, and Ninuk Dian Kurniawati}

Faculty of Nursing, Universitas Airlangga, Surabaya, Indonesia

\section{ABSTRACT}

Introduction: Hyposalivation is a common problem experienced by head and neck $(\mathrm{H} \& \mathrm{~N})$ cancer patients undergoing radiotherapy. Hyposalivation can cause negative effects on the physical aspects of making oral mucositis, pain during eating and talking as well as psychological effects that cause feeling of discomfort sadness and, ultimately, depression. Many nonpharmacological interventions can be done for hyposalivation that occur in patients, among which are chewing gum and cryotherapy because they are easy to do, easy to access, inexpensive and have minimal side effects. However, the effectiveness of these interventions is not yet clear. Hence, this study is aimed to determine the effectiveness of chewing gum versus cryotherapy to increase salivary volume in $\mathrm{H} \& \mathrm{~N}$ cancer patients undergoing radiotherapy.

Methods: A quasi-experimental time series group design to determine the most effective time to influence the increase in salivary volume. This research was conducted on 36 respondents H\&N cancer undergoing radiotherapy with four times measurement are pretest-posttest on the 3rd, 5th, and 7th day of intervention between February and March 2020. Subjects were chosen using consecutive sampling. Chewing gum group will chew gum six (6) pieces/day and cryotherapy group will suck on ice cubes five (5) minutes before and after radiotherapy. The spitting method was used to collect saliva and the data were analyzed using General Linear Model-Repeated Measure (GLMRM).

Results: Chewing gum is more effective to increase salivary volume than cryotherapy. The GLMRM within subjects at four (4) times measurement showed a significant difference between chewing gum and cryotherapy group with $\mathrm{p}$ value $<0.05$ on the 7 th day. Subjects in the chewing gum group had better salivary volume increment than cryotherapy group.

Conclusion: This study showed that chewing gum is more effective to increase salivary volume on patient $\mathrm{H} \& \mathrm{~N}$ cancer undergoing radiotherapy because chewing gum has higher salivary volume increment than cryotherapy groups.

\section{ARTICLE HISTORY}

Received: May 27, 2020

Accepted: June 15, 2020

\section{KEYWORDS}

chewing gum; cryotherapy; salivary volume; radiotherapy

\section{CONTACT}

Ninuk Dian Kurniawati $\triangle$ ninuk.dk@fkp.unair.ac.id $\doteq$ Faculty of Nursing, Universitas Airlangga, Surabaya, Indonesia

Cite this as: Sholikhah, D, U., Sudiana, I, K., \& Kurniawati, N, D. (2020). The Effectiveness of Chewing Gum versus Cryotherapy on Salivary Volume among Patient with Head and Neck Cancer Undergoing Radiotherapy. Jurnal Ners, 15(1). doi:http://dx.doi.org/10.20473/in.v15i1.19444

\section{INTRODUCTION}

Head and neck cancer is a tumor that arises in the nasal cavity, mouth. oropharynx, nasopharynx, salivary glands, paranasal sinuses, hypopharynx, and larynx (NIH. 2019). Radiotherapy is one of the three most common treatments for head and neck cancer and requires discipline and a long time (Laursen et al., 2018). Radiotherapy is a cancer treatment that uses high-energy X-rays or other types of radiation to kill cancer cells or keep cancer cells from growing (NIH, 2019). The safe dose of the parotid gland is
$26 \mathrm{~Gy}$, the safe dose of the submandibular gland is 39Gy and a 30Gy dose for minor salivary glands remains safe (Siddiqui \& Movsas, 2017). Radiotherapy doses of 60-70Gy can cause prolonged and severe problems in the mouth (Villa \& Sonis, 2015). Radiotherapy can shrink and kill tumor cells (Santoso,Surarso, \& Kentjono, 2009). but it has the most frequent side effects experienced by patients, namely hyposalivation, thickened saliva, mucosal infections, pain and taste sensory dysfunction (Epstein et al., 2017). Epstein et al. (2017) state radiation can cause problems in the mouth. 


\section{U. SHOLIKHAH, ET AL}

Hyposalivation is a common problem experienced by head and neck cancer patients undergoing radiotherapy (Siddiqui \& Movsas, 2017). The incidence of hyposalivation due to radiation was $87.5 \%-100 \%$ experienced by patients undergoing radiotherapy of the head neck area (Marinna \& Harijanti, 2017;(Surjadi \& Amtha, 2012). Continuous exposure to radiation and cytotoxic agents have several direct effects on the oral epithelium that can cause damage to the salivary gland duct cells and cause hyposalivation (Eghbali, Aziz, Taherkhanch, \& Bagheri, 2017). Hyposalivation is defined if salivary flow without stimulation is $\leq 0.2 \mathrm{~mL} / \min$ (Kaae, Stenfeldt, \& Eriksen, 2016). The volume of saliva produced per day ranges between 0.5 and $1.0 \mathrm{~L}$ in normal physiological conditions, and the physiological pH range for saliva is 6.5-7.4 (Simões, Campos, Arana-Chavez, \& Nicolau, 2015). Resting saliva flow rate (volume of saliva/collection time) is of $0.1 \mathrm{~mL} / \mathrm{min}$ or less and/or a stimulated whole saliva flow rate of $0.7 \mathrm{~mL} / \mathrm{min}$ or less (Ra'abung, Sudiana, \& Hidayati,2019). Saliva has decreased production in patients undergoing radiotherapy compared to normal people (Irna \& Subita, 2008; Surjadi \& Amtha, 2012). Hyposalivation could cause negative effects on the physical aspects of making oral mucositis, pain during eating and talking, papilla loss on chapped tongue and lips (Plemons et al., 2014) as well as psychological effects causing feelings of discomfort, sadness, and, eventually, depression (Traktama \& Sufiawati, 2018).

Hyposaliva management in Saiful Anwar Malang hospital advises to drink sufficient water and clean the mouth, but hyposalivation is still often experienced to become oral mucositis. Based on observations and interviews with head and neck cancer patients undergoing radiotherapy, there are patients who drink only a little because of pain when swallowing, so that intervention is needed that can stimulate the salivary gland without swallowing. Several methods can be done to reduce the severity of hyposaliva, one of which is by stimulating the salivary glands to keep producing saliva. Some methods used to reduce hyposaliva are chewing gum, sucking ice cubes, increasing the consumption of mineral water and cleaning the mouth (Marinna \& Harijanti, 2017). Research (Kaae et al., 2016) shows that chewing gum can stimulate saliva output that is seen at the beginning and at the end of an intervention. Findings by Epstein et al. (2017) show that cryotherapy can stimulated saliva. Previous research have carried out many studies of chewing gum or cryotherapy in patients undergoing chemotherapy (Didem, Ayfer, \& Ferda, 2014; Utami \& Hayati, 2018).

Given the importance of the role of saliva and the consequences arising from hyposalivation, it is necessary for nurses to help increasing salivary volume in head and neck cancer patients undergoing radiotherapy. Chewing gum and cryotherapy are easy, inexpensive, safe interventions done by patients to increase the volume of saliva and oral mucositis (Utami \& Hayati, 2018). The use of cold therapy can make patients feel cold and toothache so that it requires criteria. teeth in a healthy condition (no history of sensitive teeth) (Katranc et al., 2012) and strong flavors, such as peppermint or lemon, are not favored in the early phase of recovery; effects can be minimized by choosing flavors of xylitol gum such as blueberries and strawberries, but its effectiveness is unclear. Nurses play an important role in helping patients protect and maintain their oral health. This study aimed was to determine the effectiveness of chewing gum versus cryotherapy to increase the volume of saliva in head and neck cancer patients undergoing radiotherapy.

\section{MATERIALS AND METHODS}

This research was a quasi-experimental time series group design to determine the most effective time to influence the increase in salivary volume. This study involved 36 respondents who were divided into chewing gum groups and cryotherapy groups $(18 / 18)$ obtained by consecutive sampling. Respondents were taken based on inclusion criteria to reduce the effects of bias. The inclusion criteria in this study were: 1) patients having mucositis oral undergoing radiotherapy head and neck cancer; 2) Type squamous cell carcinoma because it is the most common type of cancer; 3 ) patients can chew gum or suck ice cubes, confirmed with interviews. Meanwhile, the exclusion criteria in this study are: 1) patients having sensitive tooth to minimize pain when sucking ice cubes; 2) patients having diabetes mellitus. The drop out criteria in this study include the patient dies and the patient not completing the therapy process. Data collection was carried out at Radiotherapy Installation Saiful Anwar Hospital Malang between February 2020 and March 2020.

The dependent variable was salivary volume and the independent variable was chewing gum and cryotherapy. Researchers prepared equipment such as xylitol gum, ice cube, measuring cup, mask, gloves, stationery, 3cc syringe, cellphone stopwatch, observation sheet and informed consent. Prior to the intervention, the respondent obtained an explanation of the purpose of the study and signed an informed consent as a sign of willingness to become a respondent. The researchers measured the patient's saliva volume as pre-intervention data. The researchers divided the respondents into the chewing gum group and the cryotherapy group according to the patient's condition at the beginning of the study meeting and continued for up to seven (7) days of radiotherapy. The researcher also involved the respondent's family to be willing to help in the research, especially as the supervisor of the respondent in intervening correctly and routinely. Researchers explained the interventions to be provided and educated them to keep doing the hospital standard in the form of adequate drinking and cleaning the mouth. 
Table 1. Characteristics of participants

\begin{tabular}{|c|c|c|c|c|c|c|}
\hline \multirow[t]{2}{*}{ Characteristics of participants } & \multicolumn{2}{|c|}{$\begin{array}{l}\text { Chewing Gum } \\
\text { group }(n=24)\end{array}$} & \multicolumn{2}{|c|}{$\begin{array}{c}\text { Cryotherapy group } \\
(n=18)\end{array}$} & \multicolumn{2}{|c|}{ Total } \\
\hline & $\mathbf{n}$ & $\%$ & $\mathbf{n}$ & $\%$ & $\mathbf{n}$ & $\%$ \\
\hline \multicolumn{7}{|l|}{ Gender } \\
\hline Male & 15 & 83.3 & 16 & 88.9 & 31 & 86.1 \\
\hline Female & 3 & 16.7 & 2 & 11.1 & 5 & 13.9 \\
\hline \multicolumn{7}{|l|}{ Age (year) } \\
\hline $17-25$ & 1 & 5.6 & 0 & 0 & 1 & 2.8 \\
\hline $26-35$ & 1 & 5.6 & 0 & 0 & 1 & 2.8 \\
\hline $36-45$ & 4 & 22.2 & 3 & 16.7 & 7 & 19.4 \\
\hline $46-55$ & 5 & 27.8 & 7 & 38.9 & 12 & 33.4 \\
\hline $56-65$ & 2 & 11.1 & 4 & 22.2 & 6 & 16.7 \\
\hline$>65$ & 5 & 22.2 & 4 & 22.2 & 9 & 25 \\
\hline \multicolumn{7}{|l|}{ Diagnosis of Disease } \\
\hline Nasopharyngeal cancer & 7 & 38.9 & 13 & 72.2 & 20 & 59.5 \\
\hline Oropharyngeal cancer & 1 & 5.6 & 0 & 0 & 1 & 2.8 \\
\hline Larynx cancer & 5 & 27.8 & 2 & 11.1 & 7 & 19.4 \\
\hline Non-Hodgkin's lymphoma & 1 & 5.6 & 0 & 0 & 1 & 2.8 \\
\hline Tongue cancer & 3 & 16.7 & 0 & 0 & 3 & 8.3 \\
\hline Lymphoma cancer & 1 & 5.6 & 0 & 0 & 1 & 2.8 \\
\hline Mandibula cancer & 0 & 0 & 3 & 16.7 & 3 & 8.3 \\
\hline \multicolumn{7}{|l|}{ Stage } \\
\hline Stage 1 & 0 & 0 & 1 & 5.6 & 1 & 2.8 \\
\hline Stage 2 & 10 & 55.6 & 9 & 50 & 19 & 52.8 \\
\hline Stage 3 & 6 & 33.3 & 4 & 22.2 & 10 & 27.8 \\
\hline Stage 4 & 2 & 11.1 & 4 & 22.2 & 6 & 16.7 \\
\hline \multicolumn{7}{|l|}{ Education status } \\
\hline No school & 1 & 5.6 & 2 & 11.1 & 3 & 8.3 \\
\hline Elementary school & 7 & 38.9 & 4 & 22.2 & 11 & 30.6 \\
\hline Middle school & 2 & 11.1 & 5 & 27.8 & 7 & 19.4 \\
\hline High school & 6 & 33.3 & 6 & 33.3 & 12 & 33.3 \\
\hline Bachelor & 2 & 11.1 & 1 & 5.6 & 3 & 8.3 \\
\hline \multicolumn{7}{|l|}{ Employment status } \\
\hline Farmers & 4 & 22.2 & 5 & 27.8 & 9 & 25 \\
\hline Private job & 6 & 33.3 & 6 & 33.3 & 12 & 33.3 \\
\hline Trader & 3 & 8.3 & 5 & 27.8 & 8 & 22.2 \\
\hline Civil servants & 3 & 16.7 & 1 & 5.6 & 4 & 11.1 \\
\hline Housewife & 2 & 11.1 & 1 & 5.6 & 3 & 8.3 \\
\hline \multicolumn{7}{|l|}{ Marital status } \\
\hline Married & 16 & 88.9 & 16 & 88.9 & 32 & 88.9 \\
\hline Not married & 2 & 11.1 & 1 & 5.6 & 3 & 8.3 \\
\hline Divorced & 0 & 0 & 1 & 5.6 & 1 & 2.8 \\
\hline \multicolumn{7}{|l|}{ Smoking habit } \\
\hline Not smoking & 3 & 16.7 & 3 & 16.7 & 6 & 16.7 \\
\hline 1 pack/day & 12 & 66.7 & 10 & 55.6 & 22 & 61.1 \\
\hline 2 pack/day & 2 & 11.1 & 4 & 22.2 & 6 & 16.7 \\
\hline 3 pack or more/day & 1 & 5.6 & 1 & 5.6 & 2 & 5.6 \\
\hline \multicolumn{7}{|l|}{ Length of smoking } \\
\hline Not smoking & 3 & 16.7 & 3 & 16.7 & 6 & 16.7 \\
\hline $1-10$ years & 9 & 50 & 4 & 22.2 & 13 & 36.1 \\
\hline $11-20$ years & 5 & 27.8 & 7 & 38.9 & 12 & 33.3 \\
\hline $21-30$ years & 1 & 5.6 & 4 & 22.2 & 5 & 13.9 \\
\hline
\end{tabular}

Subjects in the chewing gum group were asked to chew six pieces of sugar-free gum xylitol a day (two pieces in the morning. afternoon and evening) each about 10 minutes respectively for a week after radiotherapy session. The ingredients contained in xylitol gum are natural ingredients and artificial flavors (sorbitol, maltitol, syrup, xylitol, aspartame. acesulfame $\mathrm{K}$ ), rubber-based ingredients, binding agents (E903) and antioxidants (E321) (Jerniga, Chiung, Chen, \& Sewell, 2014; Leede, Leersum, Kroon,Weel, \& Sijp, 2018) so they are safe for consumption. Xylitol is anticaries because it is able to suppress the number of Streptococcus mutans colonies, inhibits the growth of plaque, suppresses saliva acidity and inhibits inflammation in the mouth because xylitol cannot be metabolized by oral bacteria, including Streptococcus mutans. and is a substance that plays a role in the process of glycolysis inhibition (Rodian et al., 2011). To reduce the drop out of this research involved the family and filling out the intervention check list. The family were willing to help be a reminder of respondents in conducting chewing gum interventions, namely chewing xylitol gum three (3) times a day in the 
Table 2. Salivary volume in the chewing gum and cryotherapy groups in GLMRM ANOVA within subject test

\begin{tabular}{clccc}
\hline Group & \multicolumn{1}{c}{ Time } & Mean \pm SD & Delta & p-Value \\
\hline Chewing Gum & 3rd day vs pre-test & $0.6444 \pm 0.17564$ & 0.1223 & 0.000 \\
& Day 5 vs pre-test & $0.8944 \pm 0.14337$ & 0.25 & 0.000 \\
& 7th day vs pre-test & $1.0722 \pm 0.18087$ & 0.4278 & 0.000 \\
& 7th day vs 3rd day & $0.7667 \pm 0.16088$ & 0.3055 & 0.000 \\
Cryotherapy & 7th day vs day 5 & $0.8944 \pm 0.14337$ & 0.1778 & 0.000 \\
& 3rd day vs pre-test & $0.6444 \pm 0.22287$ & 0.1112 & 0.000 \\
& Day 5 vs pre-test & $0.8611 \pm 0.16852$ & 0.2167 & 0.000 \\
& 7th day vs pre-test & $0.9611 \pm 0.15770$ & 0.3167 & 0.000 \\
& 7th day vs 3rd day & $0.7556 \pm 0.15038$ & 0.2055 & 0.000 \\
& 7th day vs day 5 & $0.8611 \pm 0.16852$ & 0.1 & 0.001 \\
\hline
\end{tabular}

Table 3. Salivary volume in the chewing gum and cryotherapy groups in GLMRM ANOVA between subject test

\begin{tabular}{lcccc}
\hline \multicolumn{1}{c}{ Saliva (ml/minute) } & $\begin{array}{c}\text { Chewing Gum } \\
\text { Mean } \pm \text { SD }\end{array}$ & $\begin{array}{c}\text { Cryotherapy } \\
\text { Mean } \pm \text { SD }\end{array}$ & $\begin{array}{c}\text { Delta (confidence } \\
\text { interval 95 \%) }\end{array}$ & p-value \\
\hline Pretest & $0.6444 \pm 0.17564$ & $0.6444 \pm 0.2228$ & $0(-0.109-0.145)$ & 1.000 \\
$3^{\text {rd day }}$ & $0.7667 \pm 0.16088$ & $0.7556 \pm 0.15038$ & $0.0111(-0.72-0.111)$ & 0.832 \\
5th day $^{\text {th day }}$ & $0.8944 \pm 0.14337$ & $0.8611 \pm 0.16852$ & $0.0333(0.060-0.138)$ & 0.527 \\
\hline
\end{tabular}

morning, afternoon and evening for about 10 minutes on the radiotherapy schedule. Subjects in the cryotherapy group were asked to suck an ice cube before and after radiotherapy session for five (5) minutes for a week. The patients suck the ice cubes evenly in the mouth area. Ice cubes were provided by researchers to facilitate patients. Posttest was held on third, fifth and seventh day of intervention.

Saliva volume measurements were carried out by the researchers themselves using the spitting method. The patient bowed his head deeply and the subject allowed the saliva to collect and flow through the lower lip into the tube and spit out the remaining saliva that did not flow. Measurements were taken five (5) times in five (5) minutes. Ethical approval was obtained from Komisi Etik Penelitian Kesehatan (KEPK) Saiful Anwar Hospital Malang with the number $400 / 017 /$ K.3/302/2020 on January 17 , 2020.

Demographic data include gender, age, education, employment status and marital status, diagnosis of disease, stage of cancer and smoking habit. Statistical tests using the General Linear Model-Repeated Measured ANOVA within subjects to determine the difference in salivary volume values pretest and posttest in each group. General Linear Model Repeated Measured ANOVA between subjects was used for showing effect of the chewing gum and cryotherapy on salivary volume between two groups.

\section{RESULTS}

Descriptive statistical analysis of the respondent's characteristics is shown in Table 1 . This study was followed by 36 patients with head and neck cancer undergoing radiotherapy divided into chewing gum intervention and cryotherapy intervention. Table 2 describes the statistical test GLMRM ANOVA within subjects of the effects of treatment on each group.
Table 3 describes the statistical test GLMRM ANOVA between subjects and the effect of treatment.

Table 1. shows that, in the chewing gum group and cryotherapy group, 31 people in this study were male and five were female and had the highest age range distribution of 46-55 years by 12 people. Nasopharyngeal cancer was the majority diagnosis with 20 people. The highest stage was stage 2 with 19 people. The education level of as many as 12 people is educated high school with 12 respondents having private job. The marital status majority are 32 married people. Smoking habit as many as 22 respondents smoking 1 pack/day and the majority over 1-10 years, 13 people.

Table 2 explains that the results of the GLM-RM ANOVA test showed that there were significant differences in salivary volume before and after the intervention of chewing gum and cryotherapy at the 4 th time of measurement with $\mathrm{p}=<0.05$. In the chewing gum and cryotherapy, the biggest delta group was on the 7th day of the intervention compared to the pretest3rd day and 5th day. Delta value of the chewing gum intervention on the $7^{\text {th }}$ day is 0.4278 and delta value on $7^{\text {th }}$ day cryotherapy is 0.3167 .

Table 3 explains that the GLMRM test results between subjects showed no significant differences in salivary volume before and after the intervention of chewing gum and cryotherapy. But the chewing gum group had better results than the mean chewing gum, which was higher by $1.0722 \pm 0.18087$, than the smaller cryotherapy, $0.9611 \pm 0.15770$, although the statistical results were $p$ values 0.058 ( $p>0.05)$.

Results of the GLM-RM (General Linear ModelRepeated Measure) ANOVA between subjects between the chewing gum group and the cryotherapy group showed that the effect of chewing gum intervention and cryotherapy on salivary volume is clearly visible after seven days of treatment. 


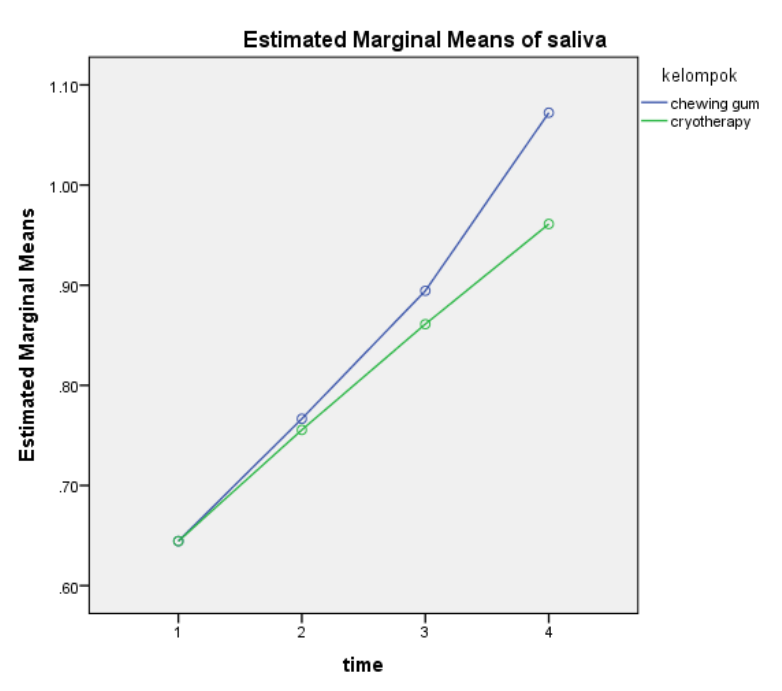

Figure 1. Graphs of salivary volume interactions (ml/min) between measurement times and between groups

\section{DISCUSSION}

Result of this study is chewing gum is more effective to increase salivary volume than cryotherapy. According to research (Pereira et al., 2016) chewing gum can increase the rate of salivary flow compared to the control group. Chewing muscles that are affected by radiation can be stimulated (Kaae et al., 2016). The main stimulus for increased salivary secretion is through mechanical stimulation (Subramaniam \& Muthukrishnan, 2019). Chewing gum is a form of mechanical stimulation that is useful for increasing saliva and $\mathrm{pH}$ (Costa, Fernandes, Quinder,De Souza, \& Pinto, 2003; Llop, Jimeno, Acien, \& Dalmau, 2010). Chewing movements can make changes in the permeability of the plasma membrane, so that calcium can enter the cell. Influx cells occur and activate several enzymes, one of which is calcinurin, which affects the process of protein production transipsi, one of which is saliva (Ambudkar, 2014) thus increasing saliva production (Eghbali et al., 2017). Factors that can affect the achievement of saliva are the patient's hydration status (Samuels, 2017). drugs consumed, sleep, fasting, nutrition and imagining food and psychological factors are sadness and depression (Plemons et al., 2014).

Previous studies do not yet know the effectiveness of chewing gum versus cryotherapy to increase saliva volume which reduces because radiation rays. Saliva is a liquid produced from several glands, namely the parotid gland, which is the largest gland, then the submandibular gland which produces serus (thin saliva, low viscosity), and the smallest gland is the sublingual gland, which produces mucus (thick saliva, viscosity is higher) (Yunus, 2008). Saliva is very important because it contains antimicrobials such as lysozyme and secretes immunoglobulin A (Subramaniam \& Muthukrishnan, 2019).

This research was conducted using time series to obtain the most effective time effect. In line with previous opinions (Plemons et al., 2014), measuring saliva periodically is an effective way to monitor changes in the volume and composition of saliva. Chewing or sucking sugar-free gum to stimulate saliva flow is an intervention to minimize dry mouth (Dental \& Ada, 2015). This study used xylitol gum because it contains lower sugar and is easy to find on the market. The results of this study support Rodian et al. (2011) that xylitol chewing gum showed the highest increase in salivary volume compared to sucrose chewing gum and probiotic gums, but the statistical tests showed no significant difference.

Cryotherapy is applied because it has many advantages in that is practical to be applied, economical, easy and has minimal side effects (Utami, 2017). The goals of cold therapy include reducing inflammation, inhibiting pain receptors, reducing edema And controlling bleeding (Rosdahl \& Kowalski, 2014).

Symptoms of a dry mouth due to reduced saliva can make a patient feel uncomfortable. disturb the appetite and quality of life (Plemons et al., 2014). Study (Dental \& Ada, 2015) states sucking ice cubes, drinking water while eating to help chew and swallow food, using mouthwash-free mouthwash, avoiding carbonated drinks (such as soda), caffeine, tobacco, and alcohol, and using lanolin-based lip balm to comfort cracked or dry lips can reduce dryness in the mouth and stimulate saliva discharge. Increased salivary secretion leads to increased volume and thinning of saliva needed for ingestion and lubrication.

In this study, not all of the patients' salivary volumes increased. This is influenced by several factors. According to Samuels (2017) drugs, smoking, and alcohol consumption will reduce the flow rate of saliva. Most respondents were aged in the range 46-65 years. Old age will make the function of the salivary glands decrease, because the acinar element turns into fat and fibrous tissue (Baird, Donehower, Stalsbroten, \& Ades,1991).

The results of this study prove that the chewing gum and cryotherapy affect the stimulus production of saliva. Hopefully, this study can increase information about nursing care in head and neck cancer, so that the symptoms caused by radiotherapy of the head and neck area can be reduced or avoided.

The limitation of this study was the researcher cannot fully control the respondent's intervention because it is done at home or boarding so this can have an impact on the result of the study. The strength of this study was there is an effective nonpharmacological action nurses can take to increase the volume of saliva in head and neck cancer patients by chewing gum. 


\section{CONCLUSION}

This study showed chewing gum is more effective to increase salivary volume than cryotherapy among patient head and neck cancer undergoing radiotherapy in Saiful Anwar Hospital Malang on $7^{\text {th }}$ day intervention. The results from this recent study hope to be useful in future health therapies to increase the volume of saliva in radiotherapy patients in the head and neck area so that it can reduce side effects and make therapy successful. What must be considered when discussing clinical application is the suitability of the gum variant. Future research is expected to control the factors that influence saliva production and conduct research by taking patients from the beginning of radiotherapy until radiotherapy is completed.

\section{ACKNOWLEDGMENT}

The author would like to express gratitude to the supervisors for the guidance and the precious suggestions, radiotherapy patients in Saiful Anwar Hospital Malang for participation in this study and the relevant authorities for their permissions to conduct this research.

\section{REFERENCES}

Ambudkar, I. S. (2014). Ca2+ signaling and regulation of fluid secretion in salivary gland acinar cells. Cell Calcium, 1-9. https://doi.org/10.1016/j.ceca.2014.02.009

Baird, S. B., Donehower, M. G., Stalsbroten, V. L., \& Ades, T. B. (1991). A cancer Source Book for Nurses (6th ed.). American Cancer Society.

Costa, E. M., Fernandes, M. Z., Quinder, L. B., De Souza, L. B., \& Pinto, L. P. (2003). Evaluation of an oral preventive protocol in children with acute lymphoblastic leukemia. Pesquisa Odontologica Brasileira, 17(2), 147-150.

Dental, A., \& Ada, A. (2015). Managing dry mouth. The Journal of the American Dental Association, 146(2),

A40. https://doi.org/10.1016/j.adaj.2014.11.019

Didem, A., Ayfer, E., \& Ferda, O. A. (2014). The Effect of Chewing Gum on Oral Mucositis in Children Receiving Chemotherapy. Health Science Journal, 8(3), 373-382.

Eghbali, Aziz., Taherkhanch., Bagheri B., S. S. (2017). Effect of Chewing Gum on Oral Mucositis in Children Undergoing Chemotherapy: A Randomized Controlled Study Original Article Effect of Chewing Gum on Oral Mucositis in Children Undergoing Chemotherapy: A Randomized Controlled Study. March 2016.

Epstein, J. B., Bensadoun, R., Saunders, D. P., \& Rajesh, V. (2017). Common oral complications of head and neck cancer radiation therapy: mucositis, infections, saliva change, fibrosis, sensory dysfunctions, dental caries, periodontal disease, and osteoradionecrosis. Cancer Medicine, 1-14. https://doi.org/10.1002/cam4.1221

Irna, \& Subita, G. P. S. (2008). Identifikasi dan Pengendalian Faktor Risiko Mukositis Oral selama Radioterapi Kanker Nasofaring Laporan Kasus. Indonesian Journal of Dentistry, 15(4), 155-162.

Jernigan, A. M., Chiung, C., Chen, G., \& Sewell, C. (2014). International Journal of Gynecology and Obstetrics CLINICAL ARTICLE A randomized trial of chewing gum to prevent postoperative ileus after laparotomy for benign gynecologic surgery in. International Journal of Gynecology and Obstetrics, 8-11. https://doi.org/10.1016/j.ijgo.2014.06.008

Kaae, J. K., Stenfeldt, L., \& Eriksen, J. G. (2016). Xerostomia after radiotherapy fo $\mathrm{r}$ Oral and Oropharyngeal cancer: increasing salivary Flow with Tasteless sugar-free chewing gum. Frontiers in Oncology, 6(May), 1-6. https://doi.org/10.3389/fonc.2016.00111

Katranc, N., Ovayolu, N., Ovayolu, O., \& Sevinc, A. (2012). European Journal of Oncology Nursing Evaluation of the effect of cryotherapy in preventing oral mucositis associated with chemotherapy e A randomized controlled trial. 16, 339-344. https://doi.org/10.1016/j.ejon.2011.07.008

Laursen, M., Specht, L., Kristensen, C. A., \& Gothelf, A. (2018). An Extended Hypofractionated Palliative Radiotherapy Regimen for Head and Neck Carcinomas. 8(June), 1-8. https://doi.org/10.3389/fonc.2018.00206

Llop, M. R., Jimeno, F. G., Acien, R, M., \& Dalmau, L. J. B. (2010). Effect of xylitol chewing gum on salivary flow rate, ph, buffering capacity and presence of Streptococcus mutans in saliva. European Journal of Paediatric Dentistry, 11(1), 9-14.

Marinna, A., \& Harijanti, K. (2017). Management of Xerostomia post Radiotherapy Nasopharingeal Carcinoma: Case Report (Y. Septorini, Wimardhani, H. Ruslijanto, H. Djuaeni, I. Sufiyawati, T. Setiani, \& A. F. Irawan (eds.)).

NIH. (2019). Salivary Gland Cancer Treatment (Adult). National Cancer Institute.

Pereira, J. V, Maciel, R. P., Jorge, M., \& Monteiro, F. (2016). Effect of Chewing Gum Containing CPPACP on Salivary Flow and Buffer Capacity : An in vivo Study. 16((1)), 425-431.

Plemons, J. M., Al-hashimi, I., \& Marek, C. L. (2014). Managing xerostomia and salivary gland hypofunction Executive. The Journal of the American Dental Association, 145(8), 867-873. https://doi.org/10.14219/jada.2014.44

Ra'abung, A. S., Sudiana, I. K., \& Hidayati, L. (2019). Pengaruh mouthwash disertai mengunyah permen karet xylitol terhadap xerostomia, laju aliran saliva, dan $p H$ saliva pada pasien yang menjalani hemodialisis. Universitas Airlangga.

Rodian, M., Satari, M. H., \& Rolleta, E. (2011). Efek Mengunyah Permen karet yang Mengandung Sukrosa, Xylitol, Probiotik terhadap Volume, 
Kecepatan Aliran, Viskositas, pH, dan Jumlah Koloni Streptococcuc Mutans Saliva.

Rosdahl, C. B., \& Kowalski, M. T. (2014). Text Book of Basic Nursing Edisi 10 (E. A. Mardella (ed.); 10th ed., p. 871). Lippincott Williams \& Wilkins/Wolter Kluwer Health.

Samuels, M. A. (2017). Radiation-induced Oral Mucositis. 7 (May). https://doi.org/10.3389/fonc.2017.00089

Santoso, B. S., Surarso, B., \& Kentjono, W. A. (2009). Radioterapi pada Karsinoma Nasofaring. THT $K L, 2$ (3), 134-141.

Siddiqui, F., \& Movsas, B. (2017). Management of Radiation Toxicity in Head and Neck Cancer. Seminars in Radiation Oncology, 27(4), 340349.

https://doi.org/10.1016/j.semradonc.2017.04. 008

Simões, A., Campos, L. De, Arana-chavez, V. E., \& Nicolau, J. (2015). Low Level Laser Therapy for hyposalivation and xerostomia. 335-339.

Subramaniam, N., \& Muthukrishnan, A. (2019). Oral mucositis and microbial colonization in oral cancer patients undergoing radiotherapy and chemotherapy: A prospective analysis in a tertiary care dental hospital. July, 1-6. https://doi.org/10.1111/jicd.12454

Surjadi, N., \& Amtha, R. (2012). Radiotherapy Reduced Salivary Flow Rate and Might Induced C. albicans Infection. 19(1), 1-6.

Traktama, D. O., \& Sufiawati, I. (2018). Keparahan mukositis oral pada pasien kanker kepala leher akibat kemoterapi dan / atau radioterapi. 4(1).

Utami, K. C. (2017). Mukositis Oral sebagai Dampak Kemoterapi pada Anak Kanker yang Mendapat Kemoterapi.

Utami, K. C., \& Hayati, H. (2018). Chewing gum is more effective than saline-solution gargling for reducing oral mucositis. Enfermería Clínica, 28, 5-8. https://doi.org/10.1016/S11308621(18)30026-3

Villa, A., \& Sonis, S. T. (2015). Mucositis : pathobiology and management. 159-164. https://doi.org/10.1097/CC0.0000000000000 180

Yunus, B. (2008). Efek samping terapi radiasi penderita kanker kepala dan leher pada kelenjar saliva. 7(1), 57-62. 